\title{
Pengetahuan Ibu Nifas Tentang Perawatan Luka Jahitan Perineum
}

Tri Maharani

Akademi Kebidanan St. Benedicta Pontianak

Informasi Artikel :

Diterima : 15 November 2020

Direvisi : 20 November 2020

Disetujui : 03 Desember 2020

*Korespondensi Penulis :

Trimaharani5@gmail.com

\section{A B S T R A K}

Persalinan seringkali mengakibatkan perlukaan jalan lahir. Luka biasanya ringan, tetapi dapat juga terjadi luka yang luas dan berbahaya sehingga dapat menyebabkan infeksi. Setelah persalinan harus selalu dilakukan pemeriksaaan vulva dan perineum. Sebagai akibat persalianan, terutama pada seorang primipara, biasa timbul luka pada vulva. Begitu juga pada robekan perineum terjadi hampir semua persalinan pertama dan juga persalinan berikutnya (Sarwono, 2008). Penelitian ini bertujuan untuk mengetahui gambaran pengetahuan ibu nifas tentang perawatan luka jahitan perineum di BPS Fransiska Pontianak. Desain Penelitian menggunakan metode deskritif dengan pendekatan survey. Penelitian ini dilaksanakan dari tanggal 26 juni 2018 sampai 8 juli 2018 dengan subjek penelitian ibu nifas yang dirawat di BPS Fransiska Pontianak. Teknik pengambilan sampel menggunakana accidental sampling. Sampel sebanyak 31 orang.Secara umum pengetahuan ibu nifas tentang pengertian dan tujuan perawatan luka jahitan perineum dikategorikan baik yaitu sebanyak 17 responden $(54,8 \%)$. Berdasarkan pengetahuan ibu nifas tentang tanda-tanda infeksi luka jahitan perineum sebanyak 18 responden $(58,1 \%)$ dikategorikan kurang. Berdasarkan cara perawatan luka jahitan perineum yaitu sebanyak 13 responden (41,9\%) dikategorikan cukup.

\section{Kata Kunci : Nifas, Luka Perineum}

\begin{abstract}
Labor often results in injury to the birth canal. The wound is usually minor, but there can also be extensive and dangerous sores that can cause infection. After labor process the vulva and perineum should always be examined. As a result of childbirth, especially in a primiparous person, it is common to develop sores on the vulva. Likewise, perineal tears occurred in almost all first deliveries and subsequent deliveries (Sarwono, 2008).This study aims to describe the knowledge of postpartum mothers about the treatment of perineal suture wounds at BPS Fransiska Pontianak. The research design used a descriptive method with a survey approach. This research was conducted from 26 June 2018 to 8 July 2018 with the research subject of postpartum mothers who were treated at BPS Fransiska Pontianak. The sampling technique used accidental sampling. A sample of 31 people. In general, the knowledge of postpartum mothers about the meaning and goals of perineal suture wound care was categorized as good, namely 17 respondents (54.8\%). Based on the knowledge of postpartum mothers about the signs of perineal suture wound infection, 18 respondents (58.1\%) were categorized as lacking.Based on the way of treating perineal suture wounds, 13 respondents (41.9\%) were categorized as sufficient.
\end{abstract}

\section{Keywords: Postpartum, Perineal Wounds}




\section{PENDAHULUAN}

Persalinan seringkali mengakibatkan perlukaan jalan lahir.Luka biasanya ringan, tetapi dapat juga terjadi luka yang luas dan berbahaya sehingga dapat menyebabkan infeksi.Setelah persalinan harus selalu dilakukan pemeriksaaan vulva dan perineum.Sebagai akibat persalianan, terutama pada seorang primipara, biasa timbul luka pada vulva.Begitu juga pada robekan perineum terjadi hampir semua persalinan pertama dan juga persalinan berikutnya (Sarwono, 2008).

Robekkan perineum umunya terjadi di garis tengah dan bisa menjadi luas apabila kepala janin lahir cepat, sehingga terjadilah perlukaan pada daerah perineum. Jaringan lunak jalan lahir dan struktur di sekitarnya akan mengalami kerusakan pada setiap persalianan. Penjahitan dilakukan agar robekkan yang besar dapat tertutup kembali dan darah tidak mengalir begitu banyak. Episiotomi dilakukan jika, kesejahteraan ibu dan janin terancam untuk mempercepat persalinan kala dua, jika janin besar (> 4000 gram), dan untuk menghindari adanya kemungkinan terjadinya perdarahan otak karena pembuluh darah rapuh (Bobak, 2005).

Berdasarkan studi pendahuluan yang dilakukan oleh peneliti pada tanggal 14 Januari 2018 melalui wawancara singkat terhadap empat ibu post partum yang sedang dirawat di ruangan nifas BPS Fransiska Pontianak yang memiliki luka jahitan perineum, ternyata tiga ibu post partum masih kurang mengerti cara perawatan luka perineum seperti cara mengganti pembalut yang benar, cara membersihkan daerah perineum yang benar, serta masih kurangnya menjaga kebersihan di daerah perineum seperti tidak mencuci tangan terlebih dahulu sebelum membersihkan daerah perineum dan tidak segera mengganti pembalut bila sudah penuh. Berdasarkan uraian di atas, maka penulis tertarik untuk mengetahui "Gambaran Pengetahuan Ibu Nifas Tentang Perawatan Luka Jahitan Perineum di BPS Fransiska Pontianak".

\section{METODE PENELITIAN}

Jenis dan desain penelitian yang digunakan dalam penelitian ini adalah menggunakan metode penelitian deskriptif dengan pendekatan survey. Penelitian deskriptif yaitu suatu metode penelitian yang dilakukan dengan tujuan utama untuk membuat gambaran atau deskripsi tentang suatu keadaan secara objektif. Populasi dalam penelitian ini adalah semua ibu nifas yang memiliki jahitan luka perineum yang ada di BPS Fransiska Pontianak sejak Januari sampai dengan Februari yang berjumlah 31 ibu.Tehnik sampling dalam penelitian ini yaitu dengan menggunakan metode Total Populasi.Dimana semua populasi dijadikan sampel penelitian. Sampel dalam penelitian ini adalah ibu-ibu post partum dengan jahitan luka perineum yang ada di ruang Nifas BPS Fransiska Pontianak dan yang berkunjung ke BPS Fransiska Pontianak yang berjumlah 31 orang. Pengumpulan data dapat dilakukan dengan cara mengumpulkan data langsung dengan membagikan kuisioner kepada para responden untuk kemudian di analisis.

HASIL PENELITIAN

1. Karakteristik Responden

Tabel 1. Distribusi Frekuensi Responden Berdasarkan Umur, Pendidikan, dan Pekerjaan

\begin{tabular}{|c|c|c|c|}
\hline \multirow{2}{*}{ No } & \multirow{2}{*}{ Karakteristik } & \multicolumn{2}{|c|}{ Total } \\
\hline & & $\mathbf{N}$ & $\%$ \\
\hline \multirow[t]{5}{*}{1} & Menurut Umur & & \\
\hline & a. $<20$ & 4 & 12,9 \\
\hline & b. $20-35$ & 22 & 71 \\
\hline & c. $>35$ & 5 & 16,1 \\
\hline & Total & 31 & 100 \\
\hline \multirow[t]{5}{*}{2} & Menurut Pendidikan & & \\
\hline & a. Dasar & 10 & 32,2 \\
\hline & b. Menengah & 18 & 58,1 \\
\hline & c. Lanjut & 3 & 9,7 \\
\hline & Total & 31 & 100 \\
\hline \multirow[t]{5}{*}{3} & Menurut Pekerjaan & & \\
\hline & a. IRT & 24 & 77,4 \\
\hline & b. Swasta & 4 & 12,9 \\
\hline & c. PNS & 3 & 9,7 \\
\hline & Total & & 100 \\
\hline
\end{tabular}

Berdasarkan tabel 1 diatas menunjukan bahwa umur ibu nifas di ruang nifas BPS Fransiska Pontianak menunjukkan bahwa sebagian besar dari responden yaitu 22 orang (71\%) berumur 20-35 tahun. Berdasarkan karateristik pendidikan, sebagaian besar dari responden yaitu 18 orang $(58,1 \%)$ berpendidikan menengah. Hampir dari seluruh responden yaitu 24 orang $(77,4 \%)$ bekerja sebagai ibu rumah tangga.

Berikut ini hasil penelitian yang dilakukan pada 31 responden dengan hasil analisis sebagai berikut :

a. Pengetahuan ibu nifas tentang pengertian dan tujuan perawatan luka jahitan perineum. 
Jurnal Kebidanan :Jurnal Medical Science Ilmu Kesehatan Akademi Kebidanan Budi Mulia Palembang Volume.10 No.2, Desember 2020

Tabel 2. Distribusi Frekuensi Pengetahuan Ibu Nifas Tentang Pengertian dan Tujuan Perawatan Luka Perineum

\begin{tabular}{llcc}
\hline \multirow{2}{*}{ No } & \multirow{2}{*}{ Kategori } & \multicolumn{2}{c}{ Jumlah } \\
\cline { 3 - 4 } & & $\mathbf{N}$ & $\mathbf{\%}$ \\
\hline 1 & Baik & 17 & 54,8 \\
\hline 2 & Cukup & 12 & 38,8 \\
\hline 3 & Kurang & 2 & 6,4 \\
\hline & Total & $\mathbf{3 1}$ & $\mathbf{1 0 0}$ \\
\hline
\end{tabular}

Berdasarkan tabel 2 diatas dapat dilihat tingkat pengetahuan ibu nifas tentang pengertian dan tujuan perawatan luka jahitan perineum menunjukan bahwa sebagian dari responden yaitu 17 orang $(54,8 \%)$ dikategorikan baik.

b. Pengetahuan ibu nifas tentang tanda-tanda infeksi luka jahitan perineum.

Tabel 3. Distribusi Frekuensi Pengetahuan Ibu Nifas Tentang Tanda-Tanda Infeksi Luka Jahitan Perineum

\begin{tabular}{cccc}
\hline \multirow{2}{*}{ No } & \multirow{2}{*}{ Kategori } & \multicolumn{2}{c}{ Jumlah } \\
\cline { 3 - 4 } & & $\mathbf{N}$ & $\mathbf{\%}$ \\
\hline 1 & Baik & 3 & 9,7 \\
\hline 2 & Cukup & 10 & 32,2 \\
\hline 3 & Kurang & 18 & 58,1 \\
\hline \multicolumn{2}{c}{ Total } & $\mathbf{3 1}$ & $\mathbf{1 0 0}$ \\
\hline
\end{tabular}

Berdasarkan tabel 3 diatas dapat dilihat tingkat pengetahuan ibu nifas tentang tandatanda infeksi luka jahitan perineum menunjukan bahwa sebagian responden yaitu 18 orang $(58,1 \%)$ dikategorikan kurang.

c. Pengetahuan ibu nifas tentang cara perawatan luka jahitan perineum.

Tabel 4. Distribusi Frekuensi Pengetahuan Ibu Nifas Tentang Cara Perawatan Luka Jahitan Perineum

\begin{tabular}{llcc}
\hline \multirow{2}{*}{ No } & \multirow{2}{*}{ Kategori } & \multicolumn{2}{c}{ Jumlah } \\
\cline { 3 - 4 } & & N & \% \\
\hline 1 & Baik & 10 & 32,3 \\
\hline 2 & Cukup & 13 & 41,9 \\
\hline 3 & Kurang & 8 & 25,8 \\
\hline & Total & $\mathbf{3 1}$ & $\mathbf{1 0 0}$ \\
\hline
\end{tabular}

Berdasarkan tabel 4 diatas dapat dilihat tingkat pengetahuan ibu nifas tentang cara perawatan luka jahitan perineum menunjukan bahwa 13 orang $(41,9 \%)$ dikategorikan cukup.

\section{PEMBAHASAN}

Berdasarkan hasil penelitian terhadap 31 responden menunjukan bahwa ibu nifas diruangan nifas BPS Fransiska Pontianak dari karakteristik responden yaitu 22 orang (71\%) berumur 20-35 tahun. Menurut Elisabeth yang dikutip Nursalam (2003) dalam (Wawan dan Dewi, 2010), usia adalah umur individu yang terhitung mulai saat dilahirkan sampai berulang tahun. Dari segi kepercayaan masyarakat seseorang yang lebih dewasa dipercaya dari orang yang belum tinggi kedewasaannya. Dari karakteristik pekerjaan 24 orang $(77,4 \%)$ adalah ibu rumah tangga.

Hal ini menunjukan banyaknya waktu ibu untuk melakukan perawatan masa nifas dibandingkan ibu-ibu yang bekerja. Menurut karakteristik pendidikan sebagian besar dari responden yaitu 18 orang $(58,1 \%)$ berpendidikan menengah. Menurut (Notoadmojo, 2003) pendidikan dapat mempengaruhi seseorang termasuk juga prilaku seseorang. Menurut Nursalem (2003) dalam (Wawan dan Dewi, 2010) pada umumnya makin tinggi pendidikan seseorang makin mudah menerima informasi dan sebaliknya semakin kurang orang menerima informasi semakin sedikit pula pengetahuan yang dimiliknya.

Pengetahuan ibu nifas tentang pengertian dan tujuan perawatan luka jahitan perineum, diperoleh sebagian dari 17 responden $(54,8 \%)$ dikategorikan baik. Hal ini disebabkan pada masa nifas terjadi perubahan anatomi dan fisiologis yang terjadi dan dialami oleh ibu.Dengan mengetahui kondisi-kondisi atau perubahan yang terjadi pada ibu nifas maka bidan memberikan asuhan masa nifas yang optimal, memberikan penyuluhan dan informasi tentang masa nifas. Hal ini diberikan selama ibu dirawat di BPS maupun saat ibu akan pulang sebagai bekal ibu untuk melanjutkan asuhan nifas terhadap diri ibu dan bayinya (Maryuni, Anik. 2009).

Pengetahuan ibu nifas tentang tanda-tanda infeksi luka jahitan perineum, diperoleh sebagian dari 18 responden $(58,1 \%)$ dikategorikan kurang. Hal ini dikarenakan kurangnya pemahaman dan pengetahuan serta informasi yang didapat oleh ibu tentang tanda-tanda infeksi pada perawatan luka jahitan perineum yang meliputi keluarnya cairan abnormal dari alat kelamin, menyebabkan gatal-gatal dan berbau, kulit tampak merah dan terasa kasar, nyeri serta panas pada tempat infeksi dan kadang-kadang perih bila kencing dan demam (Rukinah dkk, 2010).

Pengetahuan ibu nifas tentang cara perawatan luka jahitan perineum, diperoleh sebagian dari 13 responden (41,9\%) dikategorikan cukup. Hal ini sesuai dengan teori yang mengatakan sering membersihkan daerah 
perineum akan meningkatkan kenyamanan dan akan mencegah infeksi. Setelah ibu mampu mandi sendiri, biasanya daerah perineum akan dicuci sendiri, penggantian pembalut hendaknya sering dilakukan, setidaknya membersihkan perineum setelah BAB/BAK untuk mencegah infeksi. Infeksi dapat terjadi, tetapi sangat kecil kemungkinannya jika luka perineumnya dirawat dengan baik. Selama di BPS bidan akan memerikisa perineum setidaknya sekali sehari untuk memastikan tidak terjadi tanda infeksi. Bidan juga akan memberikan informasi cara menjaga kebersihan luka jahitan perineum untuk mencegah infeksi (Bahiyatun, 2009).

Perbedaan dengan penelitian sebelumnya yang serupa yang pernah diteliti oleh saudari Cornelia Waniprisa di Ruang Nifas RSUD Dokter Soedarso Pontianak hasilnya baik dan juga pernah di teliti oleh saudari Viktaria Lili Parliani di RSUD Dokter Soedarso Pontianak hasilnya juga baik, sedangkan perbedaan dengan peneliti yang dilakukan oleh peneliti sekarang terletak pada judul, waktu dan jumlah sampel yang diambil yaitu sebanyak 31 sampel dan hasil penelitian tentang "Gambaran Pengetahuan Ibu Nifas Tentang Perawatan Luka Jahitan Perineum di BPS Fransiska Pontianak Tahun 2018" hasilnya adalah cukup.

\section{KESIMPULAN DAN SARAN \\ Kesimpulan}

Setelah dilakukan penelitian terhadap 31 responden maka dapat disimpulkan bahwa, secara umum pengetahuan ibu nifas yang dirawat diruangan nifas BPS Fransiska Pontianak tahun 2018tentang perawatan luka jahitan perineum berdasarkan data yang diperoleh dapat disimpulkan bahwa : Pengetahuan ibu nifas tentang pengertian dan tujuan perawatan luka jahitan perineum, diperoleh sebagaian dari responden yaitu 17 orang $(54,8 \%)$ dikategorikan baik. Pengetahuan ibu nifas tentang tanda-tanda infeksi jahitan luka perineum, diperoleh sebagian dari responden yaitu 18 orang $(58,1 \%)$ dikategorikan kurang. Pengetahuan ibu nifas tentang cara perawatan luka jahitan perineum, diperoleh sebagian dari responden yaitu 13 orang $(41,8 \%)$ dikategorikan cukup.

\section{Saran}

Berdasarkan kesimpulan peneliti diatas, maka pada akhir penulisan karya tulis ini peneliti akan memberikan saran sebagai berikut :

\section{Institusi pendidikan}

Diharapkan dapat menambah kepustakaan dan dapat dijadikan bahan baca yang dapat digunakan dalam pengembangan penelitian bagi peneliti lainnya.

\section{Tempat penelitian}

Dapat dijadikan bahan masukan dalam membantu memberikan informasi yang benar tentang gambaran pengetahuan ibu nifas dengan perawatan luka jahitan perineum.

\section{DAFTAR PUSTAKA}

Arikunto, S. 2006. Prosedur Penelitian Suatu Pendekatan Praktik Edisi Revisi VI. Jakarta: Rineka Cipta

Bahiyatun. 2009. Asuhan Kebidanan Nifas Normal. Jakarta: EGC.

Bobak, 2005. Lowdermilk dan Jansen. 2005. Buku Ajaran Keperawatan Maternitas. Jakarta : EGC

Creasoft, 2008. Perawatan Luka Perineum pada Post Partum. Melalui Arikunto http://creasoft.wordpress.com/2008/04/21/ perawatan-luka-perineum-pada-postpartum/.

Depkes R. I. 2008. Asuhan Persalina Normal.

\section{Depkes R. I. 2007. Asuhan Persalinan Normal}

Hamilton, P. M. 2002. Dasar-dasar Keperawatan Maternitas Edisi VI. Jakarta: EGC.

Hidayat, A. 2007. Metode Penelitian Kebidanan dan Teknik Analisi Data. Jakarta: Salemba Medika.

Janah, Nurul. 2011. Asuhan Kebidanan Ibu Nifas. Jogjakarta: AR-RUZZ MEDIA.

Manuaba, I.B.G. 1998. Ilmu Kebidanan, Penyakit Kandungan dan Keluarga Berencana untuk Pendidikan, Kedokteran. Yogyakarta: Fitramaya.

Maryuni, Anik. 2009. Asuhan Pada Ibu dalam Masa Nifas (Postpartum). Jakarta: Salemba Medika.

Mubrak, dkk. 2007. Promosi Kesehatan Sebuah Pengantar Proses Belajar Mengajar Dalam Pendidikan. Yogyakarta: Graha Ilmu.

Mustika Riyani. 2011. Pengetahuan Ibu Post Partum Tentang Perawatan Jahitan Luka Perineum Di Ruang Nifas RSUD Sambas. 
Notoatmodjo, S. 2005. Metodologi Penelitian Kesehatan. Jakarta: Rineka Cipta.

Notoadmojo, 2010. Metedologi Penelitian Kesehatan. Jakarta: Rineka Cipta.

Obgyneacea, 2009. Obstetri Ginekologi. Jakarta: EGC.

Retna, E. 2009. Asuhan kebidanan Nifas. Yogyakarta: Mitra cendikia Offset.

Rukiyah, dkk. 2010. Asuhan Kebidanan 4 (Patologi). Jakarta: CV. Trans Info Media

Rukiyah, A. Y. 2009. Asuhan kebidanan II Persalinan. Jakarta: CV. Trans Info Media.

S. 2002. Prosedur Penelitian Suatu Pendekatan Praktek. Jakarta: Rineka Cipta.

Saleha, Siti. 2009. Asuhan Kebidanan pada Masa Nifas. Jakarta: Salemba Medika.

Sarwono, Prawirohardjdo. 2008. Ilmu Kebidanan. Jakrta: P.T. Bina Pustaka.

Sugiyono. 2007. Statistika untuk Penelitian. Bandung: CV.Alfabeta.

Sujiyati, dkk. 2010. Asuhan ibu nifas. Yogyakarta: cyrillus Publisher.

Sumarah, 2009. Asuhan Kebidanan II (Persalinan). Jakarta: CV. Trans Info Media.

Tarwoto, dkk. 2009. Anatomi dan fisiologi untuk Mahasiswa Keperawatan. CV. Trans Info Medika.

Tiran, D. 2005. Kamus Saku Bidan. Jakarta: EGC.

Watson, R. 2002. Anatomi dan fisiologi untuk Perawat. Jakarta: EGC.

Wiknjosastro, H. 2010. Ilmu Bedah Kebidanan. Jakarta: BP-SP 
